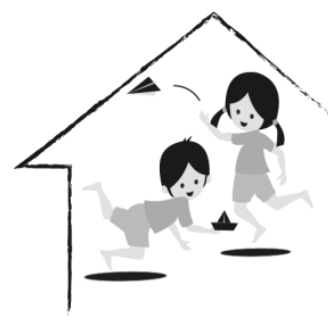

\title{
GAYA BELAJAR KINESTETIK ANAK TK MUSLIMAT NU 9 AHMAD YANI
}

\author{
Siska Maria $\mathbf{N}^{1}$, Wuri Astuti ${ }^{2}$ \\ PG-PAUD FIP Universitas Negeri Malang Jl. Semarang no. 5 Malang \\ e-mail:cikamaria4@gmail.com
}

\begin{abstract}
Kinesthetic learning styles is the acquisition of learning information by touching and moving. The purpose of this study was to determine the learning process of children with kinesthetic learning styles. This research approach uses descriptive research and qualitative research. Data collection techniques use observation, interviews, and documentation. The results of this study indicate that the characteristics of playing learning FEV children are very fond of learning through touch, the advantages possessed are being actively exploring the environment, having self-confidance, and obstacles experienced by the FEV unable to focus on learning goals because they are easily disturbed by sounds or objects in around.
\end{abstract}

\begin{abstract}
Abstrak: Gaya belajar kinestetik merupakan pemerolehan informasi belajar dengan proses menyentuh dan bergerak. Tujuan penelitian ini adalah mengetahui proses belajar anak dengan gaya belajar kinestetik. Pendekatan penelitian ini menggunakan penelitian bersifat deskriptif dan penelitian kualitatif. Teknik pengumpulan data menggunakan observasi, wawancara, dan dokumentasi. Hasil penelitian ini menunjukkan bahwa karakteristik bermain dan belajar anak FEV sangat menyukai belajar melalui sentuhan, kelebihan yang dimiliki adalah aktif bereksplorasi lingkungan, mempunyai rasa percaya diri dan hambatan yang dialami FEV tidak dapat fokus pada tujuan belajar karena mudah terganggu oleh suara-suara atau benda di sekitar.
\end{abstract}

Kata Kunci: gaya belajar kinestetik, karakteristik anak

Anak-anak merupakan pribadi yang terus berkembang sampai batas usia yang ditentukan untuk mencapai keberhasilan dalam akademik dan keterampilan. Gaya belajar yang dimiliki anakanak berbeda-beda mulai dari auditori, visual dan kinestetik. Gaya belajar setiap anak harus mendapatkan stimulus yang berbeda juga, tidak semerta-merta harus mengikuti pembelajaran yang ditentukan pendidik atau guru tetapi mengikuti dunia belajar anak. Deporter \& Hernacki (2010:110) menyatakan bahwa gaya belajar adalah kunci untuk mengembangkan kinerja dalam pekerjaan di sekolah, dan dalam situasi-situasi antar-pribadi. Felder \& Solomon (dalam Lintaj 2018: 50) menyatakan bahwa anak memiliki gaya belajar aktif, reflektif, sensitif, naluriah, virtual, dan verbal. Oleh karena itu, dunia belajar dan bermain bertujuan untuk mendukung keaktifan membangun pengetahuan dan gaya belajar anak yang berbeda.

Gaya belajar kinestetik mempengaruhi perkembangan motorik anak untuk menunjang keseimbangan gerak dalam melakukan aktivitas seperti menari, berlari, memanjat, melompat, 
bersepeda, dll. Peranan kemampuan motorik membantu anak dalam menciptakan kepuasan belajar serta aktivitas yang mendukung metabolisme tubuh anak. Gaya belajar kinestetik yang dimiliki anak dapat membantu untuk beradaptasi mengenal lingkungan sebagai sumber belajar dan bermain, serta menumbuhkan rasa percaya diri dengan dorongan untuk bertanya dalam memenuhi pengetahuan yang tumbuh dari hasil pikiran anak. O'Brien (dalam Susilowati 2013: 94) menyatakan anak dengan gaya belajar kinestetik akan belajar secara optimal dengan menyentuh, membongkar pasang dan melakukan sendiri (learning by doing).

Anak dalam lingkungan perkembangan yang sama belum tentu mempunyai kemampuan sama dalam memandang suatu objek sebagai sumber pengetahuan, anak belajar melalui pendengaran untuk mengumpulkan informasi, melihat suatu kejadian untuk menyimpulkan suatu peristiwa, menyentuh berbagai benda untuk membangun pengetahuan, hal ini merupakan beberapa cara belajar yang dilakukan anak atau bisa disebut dengan gaya belajar. Gaya belajar setiap anak dipengaruhi sikap alamiah (pembawaan) dan lingkungan pergaulan. Menurut Susilowati (2013: 90), belajar sebenarnya mengandung arti bagaimana kita menerima informasi dari dunia sekitar kita dan bagaimana kita memproses dan menggunakan informasi tersebut. Oleh karena itu, gaya belajar yang dimiliki setiap anak berbeda-beda atau kombinasi dari gaya belajar yang ada.

Proses belajar anak dengan gaya belajar kinestetik ditunjang dalam lingkungan yang menjadi sumber belajar pengetahuan. Menyusun sebuah pengetahuan untuk kegiatan anak dengan gaya belajar kinestetik diperlukan perencanaan yang matang. Dalam Bulletin Teach yang diterbitkan tahun 2018, dinyatakan bahwa pembelajar kinestetik harus didorong untuk secara produktif menggunakan kebutuhannya akan gerakan. Sreenidhi \& Tay (2017:20) menyatakan bahwa pembelajar kinestetik adalah gaya belajar dengan melakukan pembelajaran aktivitas fisik, daripada mendengarkan ceramah atau hanya melihat. Oleh karena itu, keterlibatan anak dalam berbagai aktivitas menumbuhkan rasa ingin tahu anak lebih mendalam dalam pembentukan konsep belajar yang diinginkan. Dalam memenuhi kebutuhan belajar anak, pendidik atau orangtua sebisa mungkin menyediakan benda yang nyata atau konkret.

Berkaitan dengan karakteristik anak dengan gaya belajar kinestetik, Deporter \& Hernacki (2010: 118) menyimpulkan sebagai berikut: (a) berbicara dengan perlahan, anak dengan gaya belajar kinestetik lebih memahami suatu objek melalui sentuhan, sehingga dalam mengungkapkan bahasa anak dengan gaya belajar kinestetik melakukan dengan perlahan-lahan dan berulang-ulang, (b) menanggapi perhatian fisik, anak dengan gaya belajar kinestetik berinteraksi melalui sentuhan dan sangat peka terhadap kontak fisik, perhatian juga mudah teralihkan, (c) anak dengan gaya belajar kinestetik akan menyentuh tangan, dagu, atau lengan lawan bicara agar mendapatkan perhatian saat melakukan interaksi dengan lawan bicara, (d) banyak bergerak dan selalu berorientasi pada fisik, kegiatan belajar yang melibatkan aktivitas duduk terlalu lama membuat 
anak dengan gaya belajar kinestetik tidak tahan dan menyalurkan energi gerak melalui gerakangerakan seperti pindah posisi duduk, memainkan alat tulis, menggerakkan kaki, (e) mempunyai perkembangan awal otot - otot yang besar, aktivitas gerak yang dilakukan anak dengan gaya belajar kinestetik lebih terkordinasi, sehingga kelenturan, kekuatan otot lebih baik dari anak lainnya, (f) belajar melalui memanipulasi dan praktik, kegiatan bermain merupakan kesukaan anak-anak, melalui bermain anak dapat menyalurkan energi yang dimiliki. Kegiatan memanipulasi objek anak dengan gaya belajar kinestetik dilakukan dengan menyatukan mainan sebagai objek nyata di sekitar lingkungan anak, menyusun benda seolah-olah membuat sarang, menyusun bukubuku yang digambarkan sebagai bangunan rumah, (g) menghafal dengan cara berjalan dan melihat, anak dengan gaya belajar kinestetik lebih mudah menghafal huruf dengan aktivitas berjalan melalui simbol-simbol huruf yang disediakan, (h) menggunakan jari sebagai petunjuk ketika membaca, anak dengan gaya belajar kinestetik dalam aktivitas membaca akan menggunakan jari telunjuknya untuk mengetahui tata letak kata atau huruf, (i) tidak dapat duduk diam dalam waktu lama, anak dengan gaya belajar kinestetik tidak bisa duduk diam dalam waktu lama, karena mereka lebih tertarik dengan benda-benda yang dilihat, (j) tidak dapat mengingat geografi kecuali anak dengan gaya belajar ini memang pernah berada di tempat itu, sehingga dengan melihat kembali tempat yang pernah didatangi secara spontan anak dengan gaya belajar kinestetik akan mengungkapkan kejadian yang pernah dialami di tempat tersebut, (k) kemungkinan tulisannya jelek, anak dengan gaya belajar kinestetik kurang menyukai aktivitas menulis, sehingga hasil tulisannya dibilang cukup jelas dan singkat, (l) Ingin melakukan segala sesuatu, anak dengan gaya belajar kinestetik selalu ingin melakukan semua hal secara bersamaan, dan selalu meletakkan mainan pada beberapa tempat untuk digunakan kembali, (m) menyukai permainan yang menyibukan, anak dengan gaya belajar kinestetik lebih menyukai permainan yang menyibukkan seperti leggo, masak-masakan, menyusun kartu, menggunakan stik es untuk menghasilkan bentuk, meronce, dll.

\section{METODE}

Pendekatan penelitian ini menggunakan penelitian bersifat deskriptif dan penelitian kualitatif. Penelitian kualitatif merupakan penelitian sebuah fenomena yang terjadi secara nyata. Permasalahan pada penelitian kualitatif berbeda-beda tergantung dari fenomena yang akan diangkat menjadi sebuah hasil penelitian. Memperoleh hasil penelitian kualitatif memerlukan data utama, Teknik pencarian data, pengolahan data yang relevan dan analisis hasil data. Penelitian ini mengambil 1 orang subjek penelitian yaitu anak dengan gaya belajar kinestetik di JL. Kepunden II RT 5 RW 9 Genengan-Pakisaji dan merupakan salah satu anak didik TK Muslimat NU 9 Ahmad Yani di JL. Raya Genengan No.222 Kecamatan Pakisaji Kabupaten Malang. 
Peneliti mendapatkan data melalui teknik observasi, teknik pengumpulan data wawancara, dan data dari hasil dokumentasi yang didapat. Semua data yang diperoleh dievaluasi dan dianalisis oleh peneliti untuk menghasilkan data yang relevan. Proses kelanjutan yang dilakukan peneliti adalah menulis hasil laporan penelitian yang dilakukan. Lokasi penelitian dalam penelitian ini bertempatkan pada tempat tinggal anak di JL.Kepunden RT 5 RW 9 Gang 10B Baru Genengan-Pakisaj-Malang, dan sekolah anak di TK Muslimat NU 9 Ahmad Yani di JL. Raya Genengan No.222 Kecamatan Pakisaji Kabupaten Malang.

Sumber data diperoleh dari berbagai sumber data yang akan dimanfaatkan oleh peneliti adalah: (1) Informan dari orangtua, pendidik di TK Muslimat NU 9 Ahmad Yani, kerabat terdekat untuk mengetahui latar belakang kegiatan yang dilakukan anak ketika di rumah, di sekolah dan di lingkungan anak, (2) tempat kegiatan yang dilakukan anak untuk bermain dan belajar, (3) dokumen resmi berupa hasil belajar anak, biografi, video kegiatan anak saat di rumah dan di sekolah, hasil pembelajaran anak sebagai data pendukung yang memperjelas data utama. Analisis data meliputi semua data yang diperoleh dari berbagai sumber data yaitu catatan lapangan selama observasi, wawancara, dokumentasi resmi, foto, dan sebagainya untuk mudah dipahami. Analisis data kualitatif dilakukan secara terus menerus hingga data yang diperoleh relevan. Pengumpulan data dilakukan mulai dari observasi, wawancara, mengklarifikasi, mengkondensasi, dan aktivitas penyajian data serta kesimpulan yang dihasilkan. Analisis data yang dihasil dilakukan setelah semua data terkumpul untuk menghasilkan data relevan sehingga terhindar dari kesalahan pendapat atau informasi yang diperoleh.

\section{HASIL PENELITIAN}

Hasil observasi dan wawancara di Jalan Kepunden 2 RT 5 Rw 9, peneliti menemukan identifikasi masalah pada Ananda FEV berdasarkan wawancara pada guru kelas anak, peneliti menemukan bahwa Ananda FEV: (1) tidak mau mengerjakan lembar kerja lebih dari 2 di kelas, (2) tidak mau duduk diam terlalu lama, (3) mempunyai rasa ingin tahu pada semua benda, (4) lebih suka bermain peran (5) tidak menyukai kegiatan membaca dan menulis huruf (6) berdasarkan hasil observasi dan wawancara pada orangtua juga kegiatan anak di rumah ditemukan fakta bahwa anak lebih tertarik dengan permainan di luar kelas,: (1) anak dianggap sebagai anak nakal/hiperaktif dalam lingkungan terdekat, (2) suka menyebarkan mainan pada waktu bermain, (3) anak tidak menyukai belajar menggunakan alat tulis pada kertas, (4) anak lebih suka bercerita, belajar melalui gerakan, dan bermain peran, (5) anak suka bermain memanipulasi benda-benda (6) apabila ada orang yang baru dikenal anak FEV tidak ragu bertanya dan mengajak bermain, berdasarkan wawancara dari pengasuh dan keluarga terdekat anak FEV: (1) suka bertanya ketika melihat benda atau peristiwa di sekitar, (2) waktu berbicara dengan seseorang anak akan mendekat dan menyentuh untuk mendapatkan perhatian orang tersebut, (3) suka bermain barang-barang 
(peralatan rumah tangga, media bermain), (4) jika disuruh beralasan bahwa anak FEV masih kecil dan belum besar jadi belum bisa melakukan apa yang disuruh, (5) mempunyai banyak teman, ramah terhadap tetangga. Berkaitan dengan kondisi yang dirasakan pendidik anak dengan gaya belajar kinestetik ditakutkan mengganggu aktivitas belajar yang berdampak pada anak lain dengan mengikuti apa yang dilakukan oleh anak dengan gaya belajar kinestetik.

Berdasarkan pengumpulan data dari kajian karakteristik anak yang memiliki gaya belajar kinestetik, didapatkan data anak dengan gaya belajar ini memiliki karakteristik belajar melalui sentuhan. Anak yang memiliki gaya belajar kinestetik tidak tahan hanya sekedar duduk diam, dalam waktu kurang dari 30 menit beberapa kegiatan dilakukan, kurang tertib disituasi tertentu seperti berdoa, baris-berbaris, mendengarkan petunjuk dari pendidik, dan anak dengan gaya kinestetik juga belajar melalui visual. Setelah penelitian dilakukan diperoleh gambaran data tentang anak dengan gaya belajar kinestetik.

\section{Anak dengan Gaya Belajar Kinestetik}

Anak FEV tidak menyukai kegiatan yang banyak mendengarkan atau ceramah dan selalu tidak mengikuti kegiatan pembukaan dengan tertib seperti melakukan gerakan memutar dan melompat-lompat sambil jongkok. Pada lain hari dikegiatan pembukaan pembelajaran anak juga tidak mengikuti dengan tertib sibuk bermain sendiri. Anak FEV dalam berbicara menjelaskan tentang suatu hal anak FEV menggunakan gerakan tangan, dan penekanan dalam berbicara secara pelan-pelan, menyentuh lawan bicara. Suka bergerak, tidak bisa duduk diam terlalu lama, menyukai belajar dengan praktik langsung dan memanipulasi benda-benda di sekitar.

\section{Kelebihan Anak dengan Gaya Belajar Kinestetik}

Anak FEV berkembang sangat baik dalam sosial emosional, kognitif, beberapa kompetensi bahasa, seni yang berhubungan dengan benda, dan berkembang dalam fisik motorik. Memiliki sikap empati kepedulian terhadap orang lain, ramah dan mudah berteman di lingkungan baru, mempunyai rasa kepercayaan diri, suka menyanyi lagu bahasa jepang, memiliki inisiatif membantu orangtua, tidak suka memukul teman, dan tidak mudah rewel, juga suka bertanya tentang kejadian yang dilihat.

\section{Hambatan Anak dengan Gaya Belajar Kinestetik}

Anak FEV membutuhkan ruang gerak untuk sebelum melakukan aktivitas belajar, membutuhkan beberapa kegiatan untuk menghindari kebosanan. Anak tidak dapat fokus pada tujuan belajar karena mudah terganggu oleh suara-suara atau benda di sekitar. Anak tidak sabar menunggu waktu yang lama untuk belajar. Anak tidak dapat fokus pada tujuan pembelajaran karena perhatian mudah teralihkan oleh benda atau suara di sekitar. 


\section{Upaya Yang Diberikan Untuk Anak dengan Gaya Belajar Kinestetik}

Orangtua menyediakan mainan untuk anak, memberikan kebebasan untuk anak menggunakan peralatan di rumah. Kesempatan yang diberikan pada anak membantu anak lebih kreatif, mudah mengerti kegunaan suatu benda sesuai dengan fungsinya. Mengajak anak jalan-jalan untuk berkarya wisata ke tempat terdekat untuk memberikan dukungan perkembangan pengetahuan anak tentang lingkungan. Guru kelas memberikan rangsangan sesuai dengan usia anak, memberikan alat bermain untuk menyalurkan tenaga anak sebelum pembelajaran dimulai. Memberikan kegiatan menarik untuk mengkondisikan anak.

\section{PEMBAHASAN}

Kegiatan bermain yang dilakukan anak dengan gaya belajar kinestetik adalah dengan melakukan secara langsung, menyukai permainan yang menyibukan, kurang tertib dalam beberapa situasi, tidak bisa duduk diam terlalu lama. Melalui kegiatan observasi terhadap sumber data didapatkan karakteristik anak dengan gaya belajar kinestetik sebagai berikut: (a) berbicara dengan perlahan dan mendekat ketika berbicara, anak FEV dalam berbicara menjelaskan tentang suatu hal anak FEV menggunakan gerakan tangan, dan penekanan dalam berbicara secara pelan-pelan, menyentuh lawan bicara, dalam berbicara dengan teman menjelaskan perkata dengan perlahan, ketika berbicara memiliki penekanan dan perlahan misal "nda nda nanti aku belikan kartu ultramen yang banyak lek bunda pulang sekolah di toko mainan" . cara bercerita dengan penekanan kata perlahan dan memeragakan beberapa gerakan sambil diulang-ulang, (b) berorientasi pada fisik dan banyak bergerak, FEV suka sekali bergerak baik dalam posisi duduk, pada saat makan selalu berpindah posisi duduk, berjalan memutar dan memeragakan beberapa gerakan, menyentuh beberapa benda di sekitar, kejar-kejaran di kelas bersama teman. Menarik kaki teman memutari kelas, tiduran, dan berlari memutari meja kelas. Merangkak, berjalan di kelas, duduk melakukan beberapa gerakan., (c) menanggapi perhatian fisik, anak mudah sekali menanggapi perhatian fisik seperti: mudah teralihkan oleh benda-benda disekitar, mudah teralihkan dengan mengikuti teman bermain, suka berkeliling melihat-lihat benda-benda di kelas, mendekati,melihat dan menyentuh mainan. Anak suka membuat video tentang kegiatan yang dilakukan, dan meminta kepada orangtua untuk membantu membuat video menyanyi lagu Ultramen, (d) tidak dapat berdiam diri dalam waktu lama, kegiatan yang dilakukan dengan duduk terlalu lama membuat FEV bosan dan tidak tahan duduk diam dalam waktu yang lama kecuali bermain dengan benda-benda yang diminati, aktivitas kegiatan dengan duduk yang tidak diminati membuat anak suka berjalan-jalan, berlari memutar di dalam kelas, menyentuh beberapa benda, dan tiduran di waktu kegiatan pembukaan, (e) belajar melalui praktik dan memanipulasi, FEV suka sekali belajar dengan praktik seperti memimpin doa di kelas, bermain menggunakan cat air, bermain egrang bersama anak lain, 
bermain dan belajar yang dilakukan di luar kelas, seperti main bola pimpong yang diletakkan di paralon, melompat mengikuti gambar yang disediakan, berjalan zig-zag sesuai garis, menaiki titian, menirukan gerakan senam ringan, mengikuti lomba di halaman sekolah, bermain miniatur binatang, gelembung, raket dan balon bersama kakek, dan bermain bola bersama, kegiatan praktik membuat anak menjadi lebih bersemangat, selain praktik anak FEV juga sangat menyukai kegiatan memanipulasi benda-benda disekitar seperti menggunakan benda mati seolah-olah benda hidup, melakukan kegiatan seperti gerakan memasak, mengunakan telepon bekas seolah-olah sedang berbicara dengan orang. Membuat kandang hewan dari bungkus cat air, bermain menyususun bantal seolah-olah mendirikan kemah bersama ayah, meremas-remas semangka dijadikan masakan sate kambing dan sate ayam, (f) menggunakan jari telunjuk untuk membaca dan suka berimajinasi, anak dengan gaya belajar kinestetik selalu menggunakan jari telunjuk untuk membantu pada saat membaca gambar, huruf atau angka. Bercerita dengan bahasa sendiri sambil menunjukkan gambar dibuku, selain membaca FEV juga selalu ingin melakukan semua hal seperti bercerita tentang apa yang menjadi imajinasinya, (g) menyukai permainan yang menyibukkan dan tulisan cukup baik, anak FEV menyukai permainan yang menyibukkan seperti leggo, membuat rumah dari balok, meremas-remas semangka, bermain air memandikan mainan, selain itu anak dengan gaya belajar kinestetik memiliki kemungkinan tulisan atau hasil karya yang cukup baik. Pernyataan tersebut sama dengan pendapat Deporter \& Hernacki (2010: 118) menyimpulkan sebagai berikut: (a) berbicara dengan perlahan, anak dengan gaya belajar kinestetik lebih memahami suatu objek melalui sentuhan, sehingga dalam mengungkapkan bahasa anak dengan gaya belajar kinestetik melakukan dengan perlahan-lahan dan berulang-ulang, (b) menanggapi perhatian fisik, anak dengan gaya belajar kinestetik berinteraksi melalui sentuhan dan sangat peka terhadap kontak fisik, perhatian juga mudah teralihkan, (c) Saat melakukan interaksi dengan lawan bicara anak dengan gaya belajar kinestetik akan menyentuh tangan, dagu, atau lengan lawan bicara untuk mendapatkan perhatian, (d) banyak bergerak dan selalu berorientasi pada fisik, kegiatan belajar yang melibatkan aktivitas duduk terlalu lama membuat anak dengan gaya belajar kinestetik tidak tahan dan menyalurkan energi gerak melalui gerakan-gerakan seperti pindah posisi duduk, memainkan alat tulis, menggerakkan kaki, (e) mempunyai perkembangan awal otot - otot yang besar, aktivitas gerak yang dilakukan anak dengan gaya belajar kinestetik lebih terkordinasi, sehingga kelenturan, kekuatan otot lebih baik dari anak lainnya, (f) belajar melalui memanipulasi dan praktik, kegiatan bermain merupakan kesukaan anak-anak, melalui bermain anak dapat menyalurkan energi yang dimiliki. Kegiatan memanipulasi objek anak dengan gaya belajar kinestetik dilakukan dengan menyatukan mainan sebagai objek nyata di sekitar lingkungan anak, menyusun benda seolah-olah membuat sarang, menyusun buku-buku yang digambarkan sebagai bangunan rumah, (g) menghafal dengan cara berjalan dan melihat, anak dengan gaya belajar 
kinestetik lebih mudah menghafal huruf dengan aktivitas berjalan melalui simbol-simbol huruf yang disediakan, (h) menggunakan jari sebagai petunjuk ketika membaca, anak dengan gaya belajar kinestetik dalam aktivitas membaca akan menggunakan jari telunjuknya untuk mengetahui tata letak kata atau huruf, (i) tidak dapat berdiam diri dalam waktu lama, anak dengan gaya belajar kinestetik tidak bisa duduk diam dalam waktu lama, karena anak dengan gaya belajar ini lebih tertarik dengan benda-benda yang dilihat, (j) tidak dapat mengingat geografi kecuali mereka memang pernah berada ditempat itu, anak dengan gaya belajar kinestetik tidak mudah mengingat geografi kecuali pernah berkunjung ke tempat tersebut, sehingga dengan melihat kembali tempat yang pernah didatangi secara spontan anak dengan gaya belajar kinestetik akan mengungkapkan kejadian yang pernah dialami di tempat tersebut, (k) kemungkinan tulisannya jelek, anak dengan gaya belajar kinestetik kurang menyukai aktivitas menulis, sehingga hasil tulisannya dibilang cukup jelas dan singkat, (l) ingin melakukan segala sesuatu, anak dengan gaya belajar kinestetik selalu ingin melakukan semua hal secara bersamaan, dan selalu meletakkan mainan pada beberapa tempat untuk digunakan kembali, (m) menyukai permainan yang menyibukan, anak yang memiliki gaya belajar kinestetik lebih menyukai permainan yang menyibukkan seperti leggo, masakmasakan, menyusun kartu, menggunakan stik es untuk menghasilkan bentuk, meronce, dll.

\section{SIMPULAN}

Anak FEV menyukai kegiatan bermain secara langsung seperti berlari, memanipulasi objek benda, menirukan gerakan bernyayi, dan banyak mengeskpresikan gerakan, belajar dengan praktik. Dalam lingkungan sekolah anak FEV menggunakan setiap benda yang diminati, tidak bisa duduk diam, dan cara belajar yang dilakukan berbeda dengan anak yang lain. Belajar dan bermain anak FEV adalah dengan langsung menggunakan benda-benda tersebut dan tidak menyukai kegiatan yang banyak mendengarkan atau ceramah. Aktif bereksplorasi terhadap lingkungan. FEV berkembang sangat baik dalam sosial emosional, kognitif, beberapa kompetensi bahasa, seni yang berhubungan dengan benda, dan berkembang dalam fisik motorik. FEV memiliki sikap empati kepedulian terhadap orang lain, ramah dan mudah berteman di lingkungan baru, mempunyai rasa kepercayaan diri. Hambatan yang di alami anak dengan gaya belajar kinestetik adalah membutuhkan ruang gerak sebelum melakukan aktivitas belajar, membutuhkan beberapa kegiatan untuk menghindari kebosanan. Anak tidak dapat fokus pada tujuan belajar karena mudah terganggu oleh suara-suara atau benda di sekitar.

Beberapa saran yang dapat diberikan yaitu: 1) Menyediakan beberapa macam mainan untuk anak, memberikan kebebasan untuk anak menggunakan peralatan di rumah, bercerita dan bermain peran bersama anak. 1) Mengajak anak jalan-jalan untuk berkarya wisata ke tempat terdekat untuk memberikan dukungan perkembangan pengetahuan anak tentang lingkungan. 3) Memberikan 
kegiatan yang berkaitan dengan sentuhan membuat anak tidak mudah bosan dan alat bermain untuk menyalurkan tenaga anak sebelum pembelajaran dimulai. 4) Bagi guru kelas diharapkan dapat memberikan fasilitas belajar yang menarik, sehingga anak lebih terkondisikan dan belajar sesuai dengan minat yang dimiliki. 5) Bagi peneliti selanjutnya diharapkan penelitian ini dapat dikembangkan dan diperdalam lagi.

\section{DAFTAR RUJUKAN}

Deporter, B. \& Hernacki, M. 2010. Quantum Learning. Terjemahan Alwiyah Abdurrahman. Bandung: PT Mizan Pustaka.

Deporter, B., Reardon, M., \& Nouri, S.S. 2010. Quantum Teaching. Terjemahan Alwiyah Abdurrahman. Bandung: PT Mizan Pustaka.

Lintaj,L. 2018. The Teacher, Teaching and the Learning Styles of the Students. European Journal of Education, 1 (1). Dari

https://scholar.google.co.id/scholar?start=40\&q=learning+styles+children+journal+pdf\&hl

Sreenidhi, S. K \& Tay, C. H. 2017. Styles of Learning Based on the Research of Fernald, Keller, Orton, Gillingham, Stillman, Montessori and Neil D Fleming. International Journal For Innovative Research In Multidisciplinary Field, Volume - 3, Issue - 4. Dari available online on - www.ijirmf.com.

Susilowati, R. 2013. Pemahaman Gaya belajar Pada Anak Usia Dini. Jurnal Thufula Vol.1 No.1. Dari http://garuda.ristekdikti.go.id. 